\title{
Vaginal Cancer pT2a TNM Finding v8
}

National Cancer Institute

\section{Source}

National Cancer Institute. Vaginal Cancer pT2a TNM Finding v8. NCI Thesaurus. Code C139647.

Vaginal cancer with tumor invading paravaginal tissues but not to pelvic wall, measuring $2.0 \mathrm{~cm}$ or less. (from AJCC 8th Ed.) 